\title{
$\mathrm{Al}-\mathrm{Zn}-\mathrm{Mg}$ 合金における引張変形中の転位密度変化に及ぼす 析出粒子サイズの影響
}

\author{
平田 雅裕 $^{1 *}$. 岩田 晃一 ${ }^{1}$ \\ 岡井 大祐 $^{2} \cdot$ 足立 大樹 $^{2}$
}

Journal of The Japan Institute of Light Metals, Vol. 71, No. 8 (2021), 343-348

(C) 2021 The Japan Institute of Light Metals

\section{Effect of precipitation size on dislocation density change during tensile deformation in $\mathrm{Al}-\mathrm{Zn}-\mathrm{Mg}$ alloy}

\author{
Masahiro HIRATA $^{1 *}$, Koichi IWATA ${ }^{1}$ \\ Daisuke OKADA ${ }^{2}$ and Hiroki ADACHI ${ }^{2}$
}

\begin{abstract}
Al-Zn-Mg alloys with different precipitate sizes were investigated to determine the influence of the precipitate size on the flow stress and dislocation density change during tensile deformation. The dislocation density was measured using in-situ X-ray diffraction at the SPring-8 synchrotron radiation facility with a time resolution of about $2 \mathrm{~s}$. In region II with rapid dislocation multiplication, from under-aging to peak aging, the dislocation density increased with increasing aging time. Under over-aging conditions, the amount of dislocation multiplication in region II decreased with increasing aging time. Even in region III, the increase in dislocation density with plastic deformation was the largest for the peak aging conditions. However, the amount of work hardening was small and the contribution of dislocation hardening to the strength of the material was minimal. For over-aging conditions, the increase in dislocation density in region III was smaller than for the other regions, but the amount of work hardening was relatively large. It is considered that the influence of the dislocation density on work hardening is determined by the effectiveness of precipitates as obstacles to dislocation motion.
\end{abstract}

(Received March 10, 2021 Accepted June 1, 2021)

Keywords: dislocation density; precipitation hardening; In-situ XRD; Al-Zn-Mg alloy

\section{1. 背景}

構造用金属材料として幅広く用いられているアルミニウム は, 加工硬化 $(\text { 転位強化 })^{1)}$, 結晶粒微細化強化 ${ }^{2), 3}$, 固溶強 化 $^{4)}$, 析出・分散強化 ${ }^{5)}$-7) 等の強化機構によって, 実用に耐え る高い強度を実現している。特に, 超々ジュラルミンに代表 される7000系アルミニウム合金 $(\mathrm{Al}-\mathrm{Zn}-\mathrm{Mg}$ 系合金) は析出強 化が主たる強化機構として働き,アルミニウム合金中で最も 高強度を示す。金属材料が塑性変形する際の転位運動を析出 物が阻害することにより強度が上昇するが，塑性変形の進展 に伴い新たな転位が導入され，転位密度の上昇に伴う加工硬 化が生じるため, 変形中の転位密度変化は7000系アルミニウ 么合金の機械的特性を決定する重要な因子である。

近年, 放射光を用いた引張変形中のIn-situ X線回折 (XRD) 測定による転位密度変化の測定が進められて㧈り ${ }^{8)-11)}$, 著者 らの研究グループではこれまでに, 強ひずみ加工を施した粒 径数 $\mu \mathrm{m}$ までの純アルミニウム微細粒材 ${ }^{8}$ や, 粒径 $10 \mu \mathrm{m}$ 以上

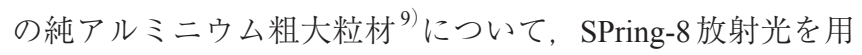
いた引張変形中 In-situ XRD 測定によって転位密度変化挙動 を調查してきた。その結果, 純アルミニウムに打ける転位密 度は4つの領域を経て変化することが判明している。領域Iは 転位密度が初期状態からほとんど恋化せず弾性変形のみで変 形が進展する領域であり，応力が $\sigma_{1}$ に達すると転位が増殖し 始め, 領域IIに移行する。この領域では転位密度が, ある転 位密度 $\rho_{\text {II }}$ まで急激に上昇し, 応力は領域 I ほどではないが, 大きく上昇し, 塑性変形と弾性変形により変形が進行する。 応力, 転位密度がそれぞれ $\sigma_{\mathrm{II}}, \rho_{\mathrm{II}}$ に達すると, 転位密度の増 加が急に緩やかとなり，領域IIIに移行し，変形はほぼ塑性変 形の久で進行する。 $\rho_{\text {II }}$ は塑性変形のみで変形が進展するため に必要な転位密度である。領域IVでは破断に伴う応力低下に 伴い, 転位密度が急激に減少する。 $\sigma_{\mathrm{I}}$ に加え, $\sigma_{\mathrm{II}}$ は降伏応力 の一種とみなすことができることから，結晶粒径変化に伴う $\sigma_{\text {III }} \rho_{\text {II }}$ の関倸を調べたところ, Bailey-Hirschの式 ${ }^{1)}$ が成り立っ たことから，結晶粒微細化強化は転位強化であることが明ら

\footnotetext{
${ }^{1}$ 兵庫県立大学工学研究科大学院生（姫路市） Graduate Student, Graduate School of Engineering, University of Hyogo（Himeji-shi, Hyogo）

2 兵庫県立大学工学研究科（广 671-2280 兵庫県姫路市書写 2167） Graduate School of Engineering, University of Hyogo (2167, Shosha, Himeji-shi, Hyogo 671-2280)

* 責任著者E-mail : em20j003@steng.u-hyogo.ac.jp
} 
かにされた

一方，7000系アルミニウム合金における代表的な強化機構 である析出強化について，その強化量を表す式として GeroldHarberkornの式 ${ }^{5)}$ や Orowanの式 ${ }^{6)}$,7) が知られており，前者は 亜時効からピーク時効領域, 後者は過時効領域における転位 運動と析出物の関係を表している。しかし，いずれの式にお いても，析出強化量は析出物半径や析出粒子間隔，体積分率 などによって説明されており，塑性変形中における転位密度 増加による影響は全く考慮されていない。そのため，塑性変 形中における強度を表すためには析出強化に加えて転位強化 を考慮する必要があるが，これら複数の強化機構が同時に働 く場合，それぞれによる寄与の単純な足し合わせで流動応力 が表現できるのかは未だ明らかになっていない ${ }^{12), 13) 。 ~}$

よって本研究では, 異なる析出物サイズを有する $\mathrm{Al}-\mathrm{Zn}-\mathrm{Mg}$ 合金を用い，変形中の転位密度変化に及ぼす析出粒子サイズ の影響を調べ，析出強化型合金の流動応力と転位密度の関係 を明らかにすることを目的とした。

\section{2. 実 験 方法}

実験には厚さ $1 \mathrm{~mm}$ の圧延まま7075 合金を用いた。発光分 析を用いて定量した実験に用いた 7075 合金の化学組成を Table 1 に示す。この試料を電気炉にて 733 K， 300 s 溶体化処

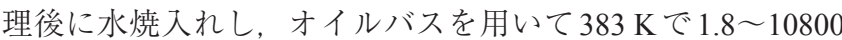
$\mathrm{ks}$ の各時間等温時効を行った。また，同様の溶体化処理と水 焼入れ後に室温時効を $36 〜 3110.4 \mathrm{ks}$ の各時間行った試料を用 意した。これらの試料の結晶粒径を調べるため, 日本電子製 走査型電子顕微鏡 JSM-6500Fに搭載したTSL製OIMを用いて 電子線後方散乱回折（EBSD）測定を行った。ダイヤモンド カッターを用いて, 縦 $10 \mathrm{~mm}$, 横 $10 \mathrm{~mm}$, 厚さ $1 \mathrm{~mm}$ に切り出 し，X線小角散乱（SAXS）測定用試料を得た。放電加工機を 用い, 圧延方向と引張方向が平行になるように平行部長さ 20 $\mathrm{mm}$, 幅 $5 \mathrm{~mm}$ の引張試験片を切り出し, 研磨によって厚さ約 $0.5 \mathrm{~mm}$ に調整した。

各時効材の析出物サイズを測定するために, SAXS 測定 ${ }^{14), 15)}$ をSPring-8 BL19B2にて行った。用いた入射X線のエネルギー は $25 \mathrm{keV}$, 露光時間 $60 \mathrm{~s}$ である。試料から $3046 \mathrm{~mm}$ 後方に DECTRIS製二次元ピクセル検出器PILATUS-2Mを設置し, 散 乱強度を測定した。得られた二次元散乱強度分布を，透過 X 線の照射位置を回転中心に全周積分することにより一次元散 乱プロファイルを得た。このプロファイルからバックグラウ ンドを除いた後, ピーク位置の散乱べクトル $k_{\mathrm{m}}\left[\mathrm{nm}^{-1}\right]$ より 以下の式から粒子間距離 $L[\mathrm{~nm}]$ を算出した ${ }^{15), 16) 。 ~}$

$$
L=\frac{7.2}{k_{\mathrm{m}}}
$$

次に, 以下の式に示す Guinierの法則 ${ }^{17)}{ }^{18)}$ を用いて析出粒 子の半径を算出した。

$$
\ln I(k)=\ln I(0)-\frac{1}{5} r^{2} k^{2}
$$

ここで， $k$ は散乱ベクトル， $I(k)$ は散乱強度， $r$ は析出物 を球状とした時の半径である。Guinierの法則は低散乱べクト ル領域において成り立つため, $\ln I(k)$ を $k^{2} に$ 対してプロッ

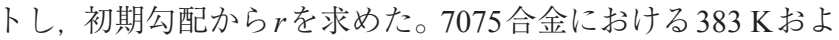

Table 1 Chemical composition of the A7075 alloy (mass\%).

\begin{tabular}{c|c|c|c|c|c|c|c|c|c}
\hline \hline $\mathrm{Zn}$ & $\mathrm{Mg}$ & $\mathrm{Cu}$ & $\mathrm{Cr}$ & $\mathrm{Fe}$ & $\mathrm{Mn}$ & $\mathrm{Si}$ & $\mathrm{Ti}$ & $\mathrm{Zr}$ & $\mathrm{Al}$ \\
\hline 5.6 & 2.6 & 1.8 & 0.18 & 0.15 & 0.02 & 0.05 & 0.01 & 0.01 & Bal. \\
\hline
\end{tabular}

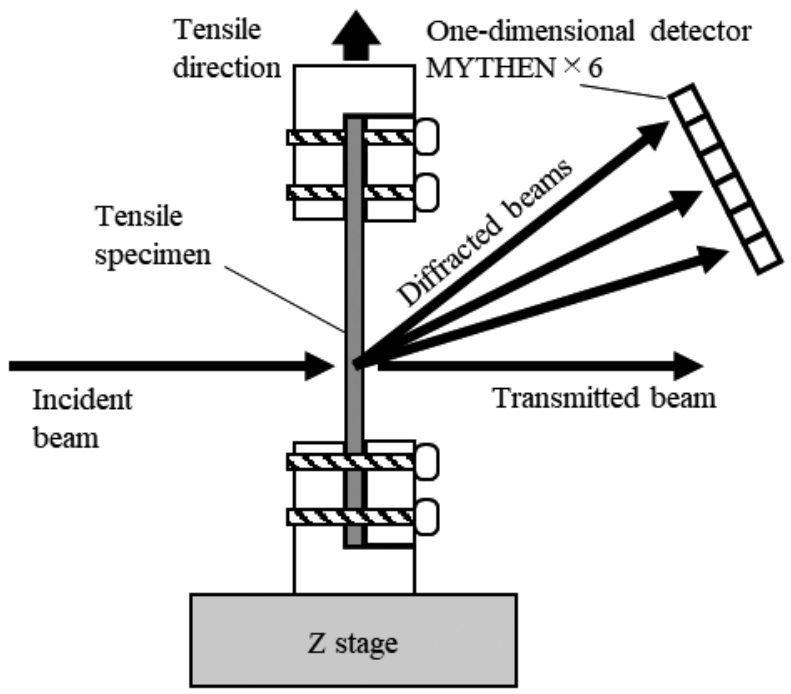

Fig. 1 Schematic diagram of in-situ XRD measurement during tensile test.

び室温時効では, 球状に近い $\eta$ 相の析出および GPゾーンの 形成が報告されている ${ }^{19), 20)}$

変形中の転位密度変化を調べるため, 引張変形中の In-situ XRD測定をSPring-8 BL19B2にて行った。測定系をFig. 1 に示 す。引張試験機をゴニオメーター上に設置し, X線の透過方 向から約 $22^{\circ}$ 上方に 6 連装 MYTHEN検出器を配置した。カメ ラ長は $720.27 \mathrm{~mm}$ である。室温にて初期ひずみ速度が $3.3 \times$ $10^{-4} \mathrm{~s}^{-1}$ の条件で引張試験を行いつつ, XRD測定を時間分解能 $2 \mathrm{~s}$ で測定を行った。得られた（111），（200），(220），(311）, (222)，（311）面からそれぞれの回折ピークの半值幅と回折 ピーク角度を求め, Williamson-Hall 法を用いて転位密度を算 出した ${ }^{8), 9), 21)}$ 。Williamson-Hall の式を以下に示す。

$$
\frac{\Delta 2 \theta \cos \theta}{\lambda}=2 \varepsilon \frac{\sin \theta}{\lambda}+\frac{0.9}{D}
$$

ここで， $\theta$ は回折角度， $\Delta 2 \theta$ は半值幅， $\lambda$ は入射 X線の波長 $(=0.491 \AA), \varepsilon$ は不均質ひずみ， $D$ は結晶子サイズである。 横軸に $2 \sin \theta / \lambda$, 縦軸に $\Delta 2 \theta \cos \theta / \lambda$ をプロットすると，傾き から不均質ひずみを求めることができる。さらに, 以下の式 を用いることで不均質ひずみから転位密度 $\rho$ を算出した ${ }^{22)}$ 。

$$
\rho=16.1\left(\frac{\varepsilon}{b}\right)^{2}
$$

ここで，16.1 はffc金属における係数，bはバーガースベク トルの大きさである。

\section{3. 結果および考察}

溶体化処理および時効処理後の試料の ND-RD断面の EBSD 測定結果をFig. 2 に示す。(a) 溶体化処理後の試料ではRD方 向に伸長した粒が見られ，ND方向における大角粒界の平均 間隔を平均結晶粒径 $d$ とすると, $15.3 \mu \mathrm{m}$ であった。(b) $383 \mathrm{~K}$, 
$36 \mathrm{ks}$ 時効材では溶体化処理材と同様の伸長粒で, $d$ は $17.1 \mu \mathrm{m}$

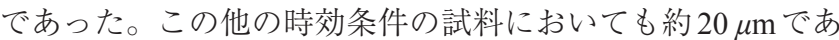
り，時効時間の変化による結晶粒径の成長はほとんど見られ なかった。純アルミニウムにおいては粒径 $5 \mu \mathrm{m}$ 以上では転位 密度変化に及ぼす結晶粒径の影響は非常に小さいため，7075 合金においても転位密度変化に結晶粒径が及ぼす影響は無視 できると考えられる ${ }^{9)}$ 。

Fig. 3 にSAXS 測定の結果から算出した $383 \mathrm{~K}$ よび室温時 効における析出粒子半径と粒子間距離 $L$ の時効時間変化を示 す。 $383 \mathrm{~K}$ 時効材では, 粒子半径は 1.2 から $5.6 \mathrm{~nm}$, 粒子間距 離は 8.0 から $25.1 \mathrm{~nm} ま て ゙$ 単調に増加し, 室温時効においても 時効時間の増加に伴って, 粒子半径, 粒子間距離は単調に増 加した。

Fig. 4 に 383 K, 10.8 ks， 180 ks， 10800 ks 時効材の In-situ XRD測定結果から算出した転位密度の変化を示す。各試料で 純アルミニウム ${ }^{8), 9)}$ と同様に, 転位密度が初期状態からほと
んど変化しない領域I，転位密度が急上昇する領域II，増加が 緩やかとなる領域IIIが観察された。10.8 ks，180 ks，10800 ks 時効材における領域I とIIの境界は破線で示しており，それぞ れ 2.13，2.90，1.45\%ひずみであった。領域 IIIでは測定した 転位密度のばらつきが大きいため, Fig. 4 から領域 II と III の 境界を判断するのは困難である。これは, 塑性変形のみで変 形が進行する領域IIIでは, 不均質ひずみが増加することに よってXRD ピークがブロードとなり強度が低下することで ピークフィッティングの精度が低下することが原因である。 例えば， $180 \mathrm{ks}$ 時効材の $11.4 \%$ ひずみにおける塑性不安定が 発生したときのXRD ピークは，最も高強度な（111）ピーク に比べ，（220） ピークは1/10，（331）ピークは1/35，（222） ピークは $1 / 70$ 程度であった。よって, 領域II と IIIの境界は以 降に示す転位密度を対数表記したグラフを用いて判断した。

Fig. 5 に析出粒子半径が $1.67 \mathrm{~nm}$ であり，亜時効領域となる $383 \mathrm{~K}, 10.8 \mathrm{ks}$ 時効材 (亜時効材) の応力ーひずみ曲線および
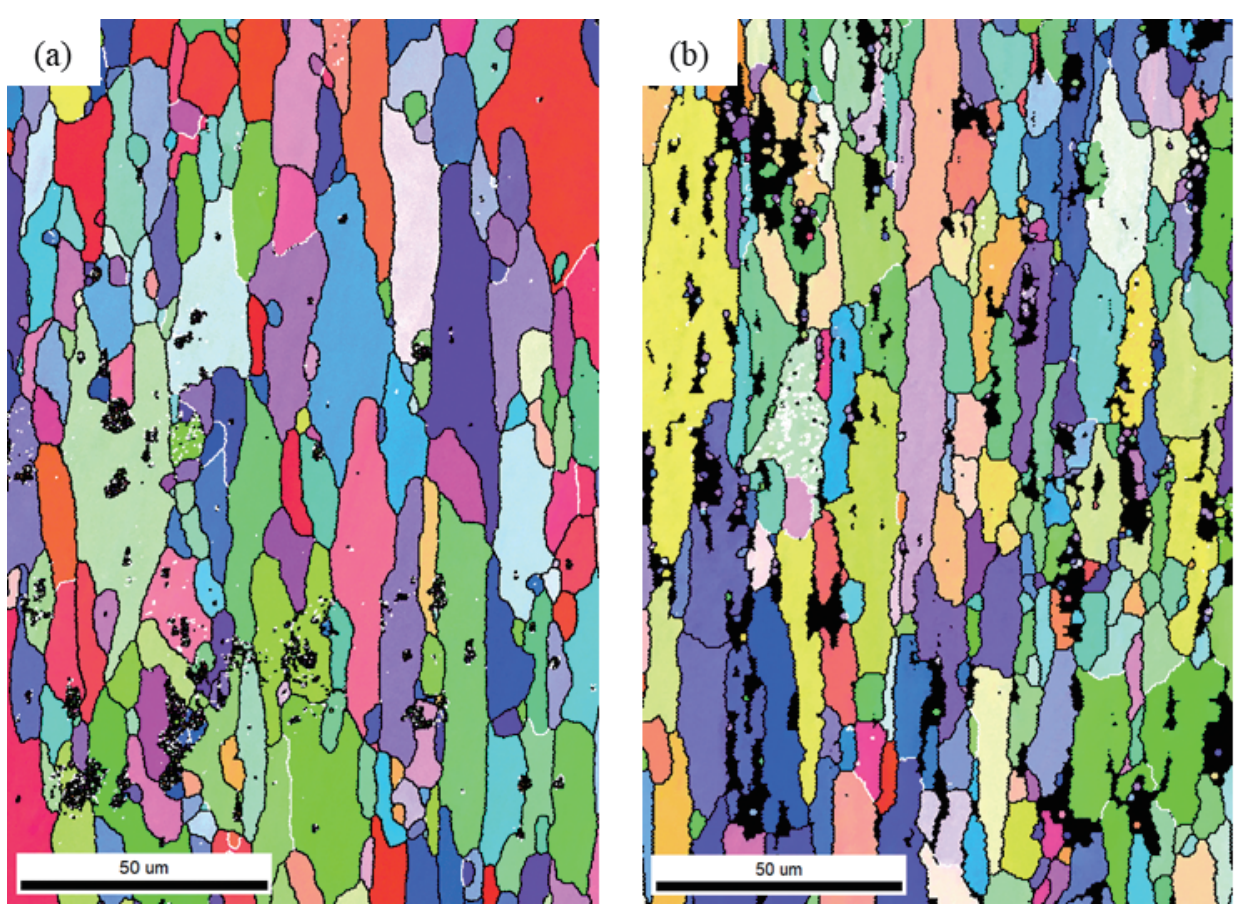

$\mathrm{RD}$

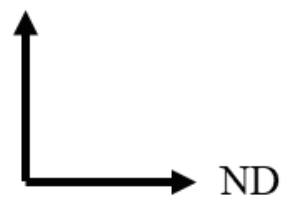

Fig. 2 TD inverse pole figure (IPF) maps of ND-RD plane obtained by EBSD measurement of 7075 alloys, in the (a) solid solution and (b) the aged at $383 \mathrm{~K}$ for $10.8 \mathrm{ks}$.
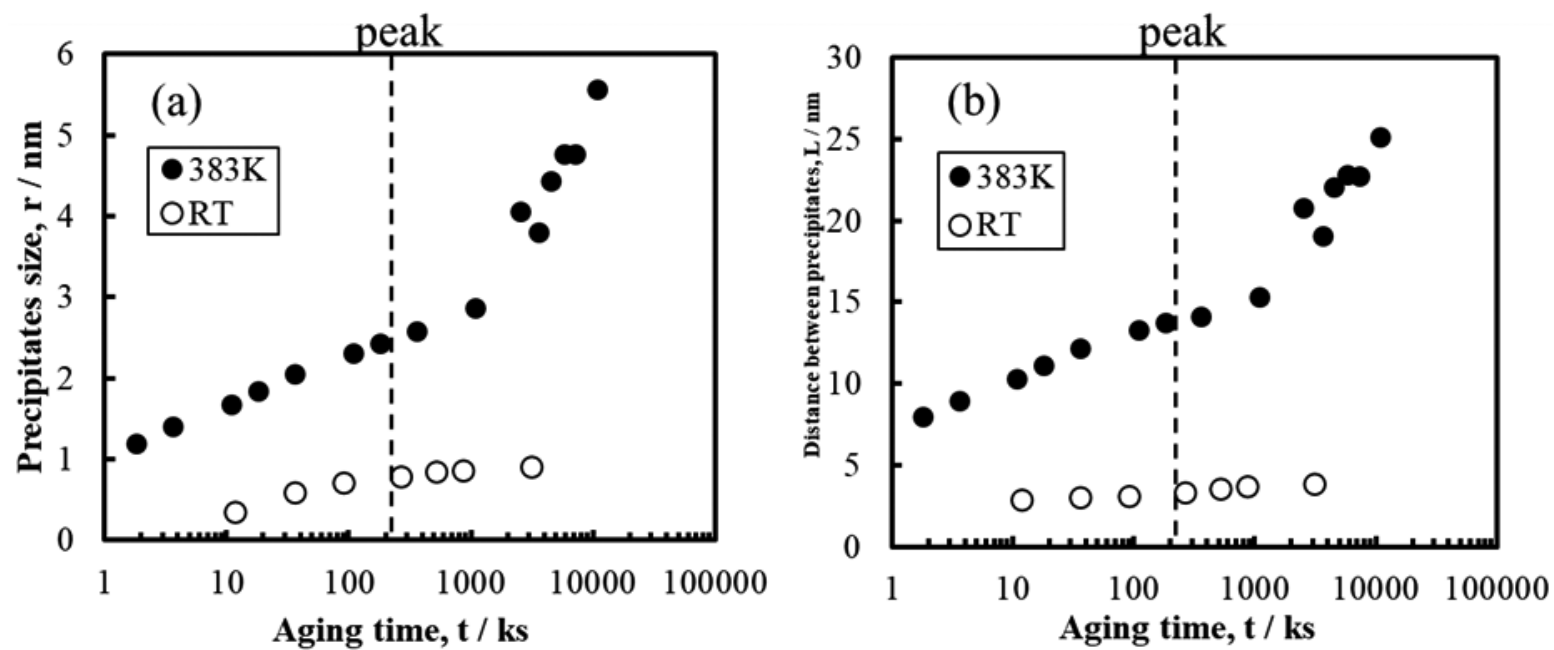

Fig. 3 Aging time dependency of the (a) precipitates size and the (b) distance between precipitates in 7075 alloys aged at $383 \mathrm{~K}$ and RT. 
転位密度変化を示す。この公称ひずみは引張試験機のスト ローク変化から計算しているため, 引張試験機の変形量が含 まれている。また，転位密度は変化傾向を理解しやすくする ため対数表記とし，4.78\%ひずみを領域II と IIIの境界とした。 領域I と II の境界における転位増殖開始応力は $\sigma_{\mathrm{I}}=351 \mathrm{MPa}$ で あった。また，領域IIでは転位密度が急激に上昇し，転位密 度 $\rho_{\mathrm{II}}=1.20 \times 10^{15} \mathrm{~m}^{-2}$ に達すると, 変化が比較的緩慢な領域III に移行した。転位密度が $\rho_{\mathrm{II}}$ に達したときの応力は $\sigma_{\mathrm{II}}=423$ $\mathrm{MPa}, 0.2 \%$ 耐力は $\sigma_{0.2}=370 \mathrm{MPa}$ であった。領域IIIでは転位密 度の緩やかな増加に伴って応力が上昇し，16.2\%ひずみで塑 性不安定が発生し最大応力を示した。応力は $\sigma_{\mathrm{TS}}=502 \mathrm{MPa}$, その時の転位密度は $\rho_{\mathrm{TS}}=2.76 \times 10^{15} \mathrm{~m}^{-2}$ であり, 領域 III 開始 時からそれぞれ $79 \mathrm{MPa}, 1.56 \times 10^{15} \mathrm{~m}^{-2}$ 上昇した。同程度の粒 径を有する純アルミニウムではそれぞれ $40 \mathrm{MPa}, 5.87 \times 10^{14}$ $\mathrm{m}^{-2}$ であったことから，亜時効材におけるこれらの増加量が 非常に大きいことがわかる。以後, 領域 III 開始時の応力 $\sigma_{\mathrm{II}}$, 転位密度 $\rho_{\mathrm{II}}$ から $\sigma_{\mathrm{TS}}, \rho_{\mathrm{TS}}$ までの増加量を領域IIIにおける加工 硬化量，転位密度増加量として扱う。

次に, ピーク時効条件である $383 \mathrm{~K}, 180 \mathrm{ks}$ 時効材の応力 ひずみ曲線および転位密度変化を Fig. 6 に示す。この時の析 出粒子半径は $2.43 \mathrm{~nm}$ である。亜時効材と同様に対数表記し た転位密度の変化から $4.50 \%$ ひずみを領域 II と III の境界とし た。このとき， $\sigma_{\mathrm{I}}=469 \mathrm{MPa}, \sigma_{0.2}=506 \mathrm{MPa}, \sigma_{\mathrm{II}}=533 \mathrm{MPa}$ で あった。亜時効材およびピーク時効材では，転位は障害物で ある析出物を剪断して移動する粒子剪断機構が働いているた め, 析出粒子半径の増加に伴って強度が上昇した ${ }^{14)}$ 。領域 II では転位密度が $\rho_{\text {II }}=1.63 \times 10^{15} \mathrm{~m}^{-2}$ に達するまで急激に増加 し，その後の領域IIIでは亜時効材と同様に応力と転位密度が 上昇した。11.4\%ひずみにおける塑性不安定が発生したとき の最大応力は $\sigma_{\mathrm{TS}}=567 \mathrm{MPa}$, その時の転位密度は $\rho_{\mathrm{TS}}=3.20 \times$ $10^{15} \mathrm{~m}^{-2}$ であり, 領域IIIにおける加工硬化量と転位密度増加 量はそれぞれ $34 \mathrm{MPa}, 1.57 \times 10^{15} \mathrm{~m}^{-2}$ であった。転位密度増加 量は純アルミニウムよりも5 倍程度大きかったのに対し，加 工硬化量は純アルミニウムよりもむしろ小さかった。

次に Fig. 7 に 383 K, 10800 ks 時効材（過時効材）の応力ひずみ曲線および転位密度変化を示す。この時の析出粒子半 径は $5.6 \mathrm{~nm}$ であり，対数表記した転位密度の変化から領域 II と IIIの境界は $2.30 \%$ ひずみ， $\sigma_{\mathrm{I}}=188 \mathrm{MPa} ， \sigma_{0.2}=234 \mathrm{MPa}, \sigma_{\mathrm{II}}$ $=235 \mathrm{MPa}$ であった。過時効材では転位は障害となる析出物 を剪断できず，Orowanループを残して移動する Orowan 機構 が働いたことにより，粒子剪断機構が働いた亜時効材，ピー ク時効材と比較して大きく強度が低下した ${ }^{14), 23)}$ 。領域IIにお いて転位密度は $\rho_{\mathrm{II}}=1.07 \times 10^{15} \mathrm{~m}^{-2}$ まで増加し, 領域IIIに移行 した。10.0\%ひずみにおける塑性不安定が発生したときの最 大応力は $\sigma_{\mathrm{TS}}=272 \mathrm{MPa}$ ，その時の転位密度は $\rho_{\mathrm{TS}}=2.10 \times 10^{15}$ $\mathrm{m}^{-2}$ であり，領域IIIにおける加工硬化量と転位密度増加量は それぞれ $37 \mathrm{MPa}, 1.03 \times 10^{15} \mathrm{~m}^{-2}$ であった。加工硬化量, 転位 密度増加量ともに亜時効およびピーク時効材と比較して小さ く，これらは亜時効材，ピーク時効材，過時効材でそれぞれ 異なる変化を示した。

$10.8 \mathrm{ks}$ 亜時効材, $180 \mathrm{ks}$ ピーク時効材, $10800 \mathrm{ks}$ 過時効材の 転位増殖開始応力はそれぞれ $\sigma_{\mathrm{I}}=351,469,188 \mathrm{MP}$ であり, 同程度の粒径を有する純アルミニウムの $\sigma_{\mathrm{I}}=22 \mathrm{MPa}$ と比較し ていずれも非常に大きかった。これは，転位源，例えばFrank-

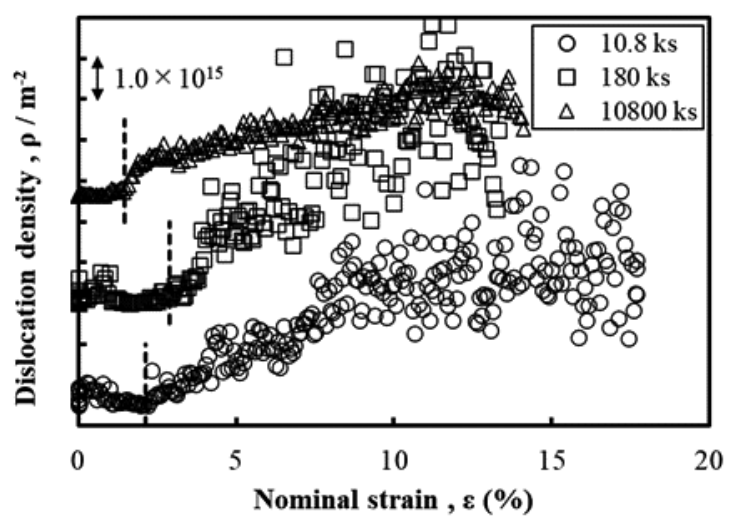

Fig. 4 Changes in dislocation density during tensile deformation in 7075 alloys aged at $383 \mathrm{~K}$ for $10.8,180$ and $10800 \mathrm{ks}$.

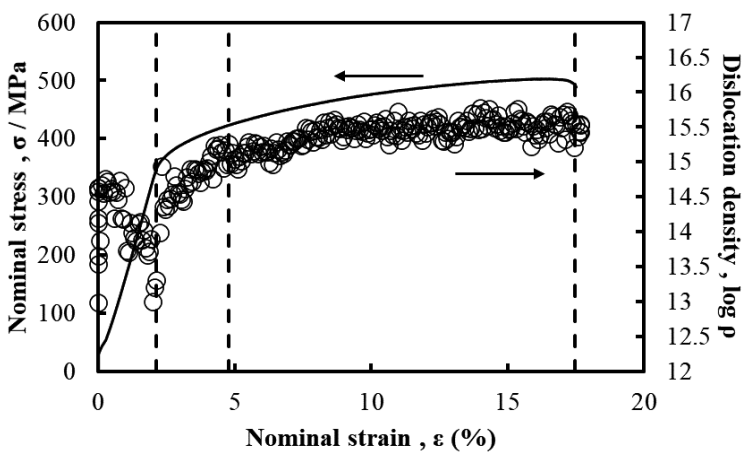

Fig. 5 Changes in stress and dislocation density by stroke change in 7075 alloy aged at $383 \mathrm{~K}$ for $10.8 \mathrm{ks}$.

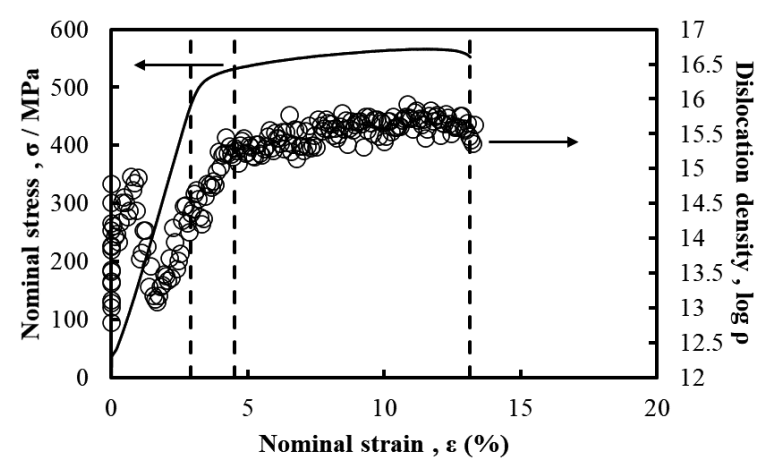

Fig. 6 Changes in stress and dislocation density by stroke change in 7075 alloy aged at $383 \mathrm{~K}$ for $180 \mathrm{ks}$.

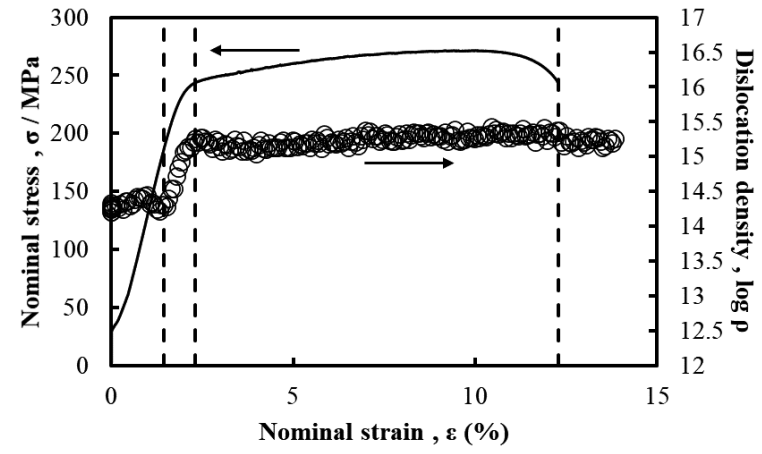

Fig. 7 Changes in stress and dislocation density by stroke change in 7075 alloy aged at $383 \mathrm{~K}$ for $10800 \mathrm{ks}$. 
Read源の転位が張り出し, 増殖するためには, 固溶元素や析 出物といった障害物を乗り越えなければならないため，転位 増殖に必要な応力が増加したことが原因と考えられる。ま た，Fig. 5〜7の応力ーひずみ曲線㧍よび転位密度変化より， 時効が進むにつれて領域II開始直後の加工硬化率揖よび転位 密度増加率は大きくなっており, 従来の降伏応力として扱わ れてきた $\sigma_{0.2}$ は $10.8 \mathrm{ks}$ 亜時効材, $180 \mathrm{ks}$ ピーク時効材， 10800 $\mathrm{ks}$ 過時効材の場合でそれぞれ $\sigma_{\mathrm{I}}$ に近い值, $\sigma_{\mathrm{I}}$ と $\sigma_{\mathrm{II}}$ の中間の值, $\sigma_{\text {II }}$ に近い值となり， $\sigma_{0.2}$ が表す降伏応力が転位増殖開始時の 応力から転位増殖後の応力へと変化している。このように, $\sigma_{0.2}$ は時効の段階によって転位増殖の有無が異なっているが, 粒子剪断機構やOrowan機構などの析出強化の式には転位密 度の項が無いため, これらの強化量を論じる際に転位増殖の 有無を考慮する必要性を示唆している。

Fig. 8 に $\rho_{\text {II }}$ の $1 / 2$ 乗と $\sigma_{\text {III }}$ の関係を示す。併せて, 粒径の異な るA1200合金における $\rho_{\text {II }}$ と $\sigma_{\text {III }}$ の関係を破線で示す。A1200合 金では転位の運動を阻害する障害物は他の転位であるため, この線は転位強化を表していると考えられる9)。GPゾーンが 形成される RT 時効材は全て亜時効条件であり， $383 \mathrm{~K}$ 時効材 に扔ける亜時効からピーク時効では，すなわち粒子剪断機構 領域である。この領域では時効の進行に伴い，転位強化を表 すA1200合金の Bailey-Hirsch 関係 $\sigma_{\text {II }}=6.30 \times 10^{-6} \rho_{\text {III }}{ }^{1 / 2}$ から大き く乘離することが明らかとなった。一方で, Orowan領域であ る過時効材では，時効時間の進行に伴ってA1200合金の Bailey-Hirsch 関係の直線に值が近づく。Fig. 9 に亜時効初期 材, ピーク時効材, 過時効材の領域IIIに扔ける転位密度と応 力の関係を示す。領域III の前半における転位密度 $\rho$ と応力 $\sigma$ の関倸は時効条件の違いによって傾きが大きく異なる直線で 表された。しかし, 領域IIIの後半では直線からの逸脱が多く 見られた。これは, 変形の進展に伴ってXRDピークの強度が 低下し，Fig. 4で示したように算出した転位密度のばらつき が大きくなるためである。また，転位密度が高くなる領域III の後半では転位の再配列，セル形成などが発生すると考えら れ，Williamson-Hall法㧍よび式（4）による転位密度の計算が 成り立たなくなると考えられる。よって，これらの影響が少 ない変形の前半部分を用いて，直線の式を計算した。 $10.8 \mathrm{ks}$ 亜時効材では $\sigma=395+1.20 \times 10^{-6} \rho^{1 / 2}, 180 \mathrm{ks}$ ピーク時効材で は $\sigma=522+6.11 \times 10^{-7} \rho^{1 / 2}, \quad 10800 \mathrm{ks}$ 過時効材では $\sigma=98.0+$ $4.26 \times 10^{-6} \rho^{1 / 2}$ であった。直線の傾き $k$ の時効時間による変化 を Fig. 10 に示す。溶体化処理直後の $3.93 \times 10^{-6}$ から時効時間 の経過に伴って低下し， $50 \mathrm{ks}$ から $1080 \mathrm{ks}$ 時効材で最小の約 $0.5 \times 10^{-6}$ を示した後, $2520 \mathrm{ks}$ 以降の過時効領域では再び上昇 し， $10800 \mathrm{ks}$ 過時効材ではむしろ溶体化処理直後より大きい 值を示した。領域IIIに打ける転位密度増加が強度上昇に及ほ す影響は，析出粒子サイズにより大きく変化することが明ら かとなった。

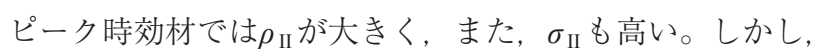
塑性変形領域である領域盀に扔いては，転位密度増加量は大 きいものの, 強度の増加が最小である。これはなぜであろう か。塑性変形領域に扔いて，せん断ひずみ速度 $\dot{\gamma} は$ Orowanの 式より

$$
\dot{\gamma}=\rho_{\mathrm{m}} b \bar{v}
$$

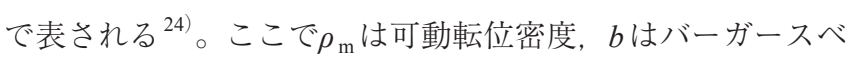

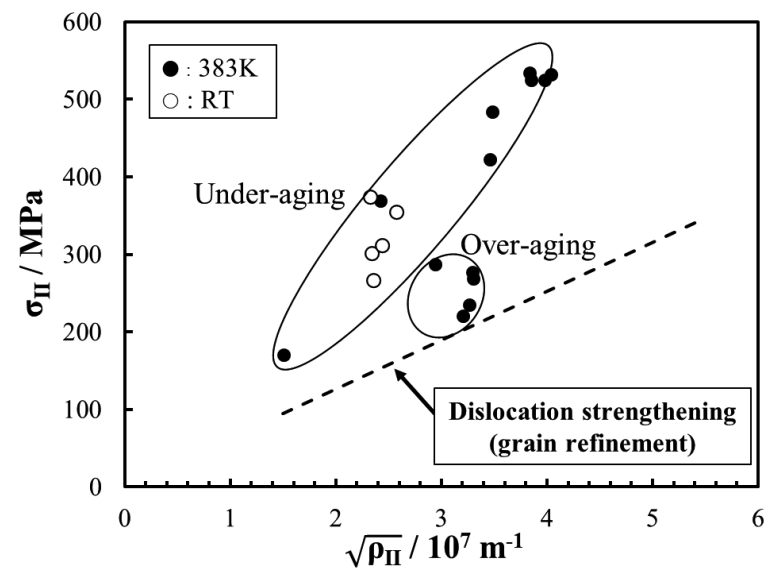

Fig. 8 Relationship between $\sigma_{\text {II }}$ and $\rho_{\text {II }}$ in 7075 alloys with various aging time. The dotted line shows the relationship in A1200 alloy ${ }^{8), 9)}$.

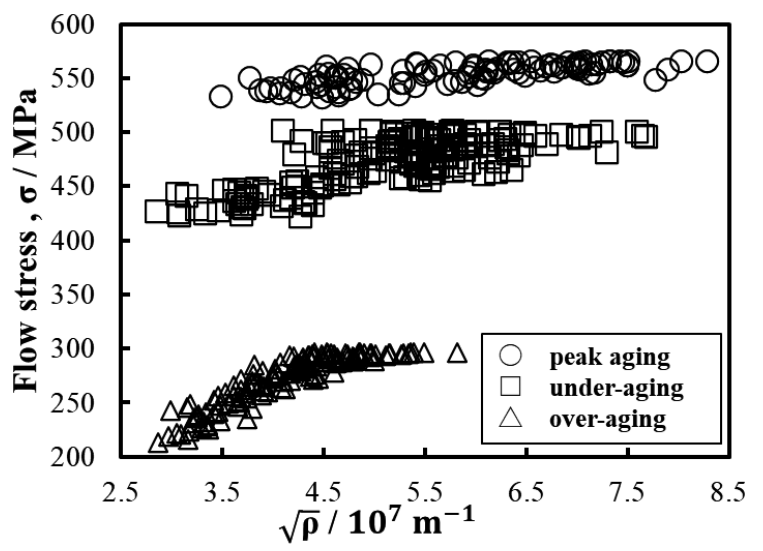

Fig. 9 Relationship between $\sigma$ and $\rho$ during the stage III in 7075 alloys aged at $383 \mathrm{~K}$.

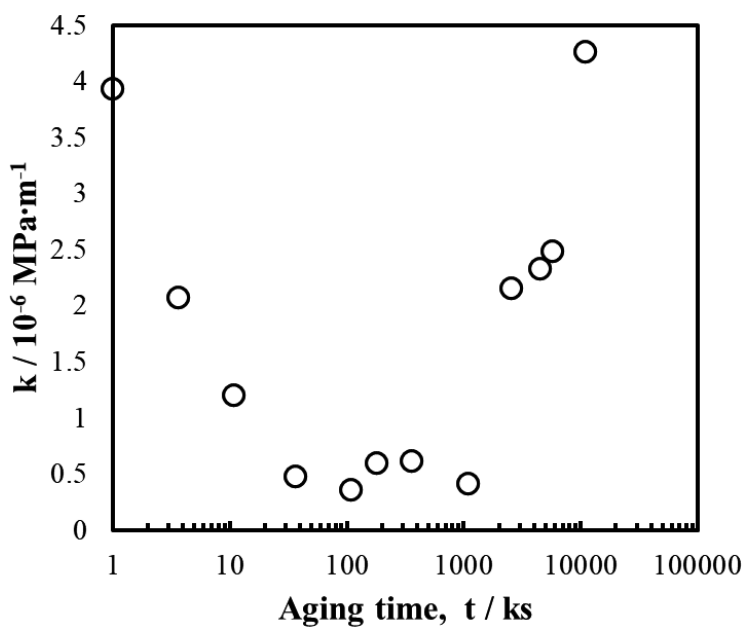

Fig. 10 Aging time dependency of the slope of the BaileyHirsch relationship during the initial stage III.

クトルの大きさ， $v$ は転位の平均移動速度である。引張速度 一定であるため方は一定とみなすことができ， $b$ も一定であ るため, $\bar{v}$ の増加・減少により $\rho_{\mathrm{m}}$ が減少もしくは増加する。

運動する転位にとって障害物となるのは他の転位と析出物 である。障害物としての強さは析出物の方が強く, 亜時効か らピーク時効に時効が進むにつれて析出物を転位が切断しづ らくなるため ${ }^{5)}$ ，障害物としての強さは増加する。それに伴 
い転位の平均速度は低下し, あるせん断ひずみ速度で変形す るために必要な転位密度, つまり $\rho_{\text {II }}$ は増加する。また, 応力 $\sigma_{\text {II }}$ は析出物を転位が乗り越える過程によって決定するため, 析出物の障害物としての強さが増加するに伴い， $\sigma_{\text {II }}$ は増加す る。

しかし，過時効となり Orowan領域に入ると，析出物の粗大 化により転位が析出物をバイパスして進むため ${ }^{6), 7)}$, 析出物 の障害物としての強さは大きく低下することにより転位の平 均速度は増加し， $\rho_{\mathrm{II}}$ は低下する。また，析出物の障害物とし ての強さが低下するに伴い， $\sigma_{\mathrm{II}}$ は低下する。そのため, $\rho_{\mathrm{II}}$ と $\sigma_{\text {II }}$ は過時効により, Fig. 8 に示すようにA1200合金の BaileyHirsch 関係に近づくと考えられる。このことは析出物の粗大 化が進行すると析出物の障害物の強さは転位の障害物のそれ に近づくことを示唆している。

一方，領域吕では，塑性変形の進行により転位密度が徐々 に増加し, 最大応力時には $\rho_{\mathrm{II}}$ の時に比べて約 2 倍まで増加す る。よって，この領域の強度を考える上において，障害物と なりうる他の転位の密度をより大きく考慮しなければならな い。亜時効と過時効では転位の障害物としての強さは比較的 大きいため, 流動応力は析出物を転位が乗り越える過程に加 え，他の転位を乗り越える過程の両方によって決定するた め, 転位密度の増加により加工硬化する。一方，ピーク時効 材では，析出物の障害物としての強さが転位に比べて非常に 大きいため，主に流動応力は析出物を転位が乗り越える過程 により決定され，転位密度の増加による流動応力の増加，つ まり加工硬化量は小さくなると考えられる。

以上のことから，析出強化型合金における加工硬化量は転 位密度変化だけでは決定されず，転位移動に対する析出物と 転位の障害物としての強さの相対的な関係によって決まるた め, 流動応力ゃ最大応力は析出強化と転位強化の単純な足し 合わせによって表すことは困難である。

\section{4. まと め}

放射光を用いた引張変形中の In-situ XRD 測定によって, $\mathrm{Al}-\mathrm{Zn}-\mathrm{Mg}$ 合金の転位密度変化に及ぼす析出物サイズの影響 を調べることによって以下の知見を得た。

（1）引張変形中の転位密度のIn-situ測定によって， $\sigma_{0.2}$ は時 効時間の経過に伴って転位増殖開始時の応力から転位増殖後 の応力へと変化していることが明らかとなった。しかし，従 来の析出強化の式には転位密度の項は存在しないため, 析出 物による強化量を論じる際には転位増殖の有無を考慮する必 要性が示唆された。

(2) $\rho_{\mathrm{II}}$ と $\sigma_{\mathrm{II}}$ の関係において, 粒子剪断領域である亜時効領 域およびピーク時効では時効時間の増加に伴って転位強化を 表す Bailey-Hirsch 関係から大きく乘離する結果となった。一 方で Orowan 領域となる過時効領域では時効時間の増加に伴 い転位強化を表す Bailey-Hirsch 関係に近づた。粒子剪断領 域では析出物の障害物としての強さが非常に大きいため, 転 位の移動速度が低下し転位密度 $\rho_{\text {II }}$ が上昇, 応力 $\sigma_{\text {II }}$ 析出物サ イズの増加に伴って上昇する。しかし，Orowan領域では転位 が析出物をバイパスして進むため, 転位の移動速度は増加し 転位密度 $\rho_{\text {II }}$ が低下する。また, 析出物の障害物としての強さ が低下するに伴って応力 $\sigma_{\text {II }}$ 低下する。
（3）領域 III における転位密度増加量に対する加工硬化量 は亚時効初期からピーク時効にかけて低下し，過時効に至る と増加した。亜時効初期材および過時効材では析出物の障害 としての強度が比較的小さく，流動応力は析出物を転位が乗 り越える過程に加え，他の転位を乗り越える過程の両方に よって決定するため，転位密度の増加により加工硬化する。 しかし，ピーク時効材では析出物の障害としての強度が非常 に大きいため, 流動応力に及ぼす他の転位を乗り越える過程 の影響が小さく，加工硬化量も小さくなる。

\section{謝 辞}

本研究は株式会社UACJより試料提供を受けた。本研究の 一部は公益財団法人軽金属奨学会の助成により行われた。本 研究の放射光実験は公益財団法人高輝度光科学研究センター SPring-8 の BL19B2（課題番号：2016A1728, 2017B1023, 2019 A1744）にて行われた。ここに謝意を表する。

\section{参 考 文 献}

1) J.E. Bailey and P.B. Hirsch: Philos. Mag., 5 (1960), 485-497., $10.1080 / 14786436008238300$

2) E. O. Hall: Proc. Phys. Soc. Sect. B, 64 (1951), 747-752.

3) N. J. Petch: J. Iron Steel Inst., 174 (1953), 25-28.

4) H. W. King: J. Mater. Sci., 1 (1966), 79-90., 10.1007/BF00549722

5) V. Gerold and H. Haberkorn: Phys. Status Solidi, 16 (1966), 675-684., 10.1002/pssb.19660160234

6) E. Orowan: Symposium on Internal Stresses in Metals, Institute of Metals, London, (1948).

7) P. B. Hirsch and F. J. Humphreys: Physics of Strength and Plasticity, ed. by A. S. Argon, MIT Press, (1969)

8) H. Adachi, Y. Miyajima, M. Sato and N. Tsuji: Mater. Trans., 56 (2015), 671-678., 10.2320/matertrans.L-M2015803

9) H. Adachi, H. Mizowaki, M. Hirata, D. Okai and H. Nakanishi: Mater. Trans., 62 (2021), 62-68., 10.2320/matertrans.L-M2020861

10) S. Gao, T. Yoshimura, W. Mao, Y. Bai, W. Gong, M.H. Park, A. Shibata, H. Adachi, M. Sato and N. Tsuji: Crystals, 10 (2020), 1-15., 10.3390/ cryst10121115

11) Y. Miyajima, S. Okubo, T. Miyazawa, H. Adachi and T. Fujii: Philos Mag. Lett., 96 (2016), 294-304., 10.1080/09500839.2016.1218563

12) A.J. Ardell: Metall. Trans. A, 16 (1985), 2131-2165., 10.1007/ BF02670416

13) S. Queyreau, G. Monnet and B. Devincre: Acta Mater., 58 (2010), 5586-5595., 10.1016/j.actamat.2010.06.028

14）長村光造，落合庄治郎，上原利弘：軽金属， 34 (1984)，517524., 10. 2464/jilm. 34. 517

15）山本哲也, 足立大樹, 奥田浩司, 長村光造, 横江一彦, 楠井 潤，横手隆昌：軽金属, 48 (1998)，242-247., 10.2464/jilm.48.242

16) K. Osamura, H. Okuda and S. Ochiai: Scr. Metall., 19 (1985), 13791384., 10.1016/0036-9748 (85) 90071-7

17) A. Guinier and G. Fournet: Small-Angle Scattering of X-Rays, John Wiley \& Sons., New York (1955)

18）松岡秀樹：日本結晶学会誌, 41 (1999), 213-226, https://doi. org $/ 10.5940 /$ jcrsj. 41.213

19) L.F. Mondolfo, N.A. Gjostein and D.W. Levinson: Trans. AIME, 8 (1956), 1378-1385.

20) H. Schmalzried and V. Gerold: Z. Metalk., 50 (1959), 568.

21) G.K. Williamson and W.H. Hall: Acta Metall., 1 (1953), 22-31., 10.1016/0001-6160 (53) 90006-6

22) G.K. Williamson and R.E. Smallman: Philos. Mag., 1 (1956), 34-46., $10.1080 / 14786435608238074$

23) K. Osamura, K. Kohno, H. Okuda, S. Ochiai, J. Kusui, K. Fujii, K. Yokoe, T. Yokote and K. Hono, Mater. Sci. Forum, 217-222 (1996), 1829-1834., 10.4028/www.scientific.net/msf.217-222.1829

24) E. Orowan: Proc. Phys. Soc., 52 (1940), 8-22., 10.1088/0959$5309 / 52 / 1 / 303$ 